\title{
Renstra Bisnis Spare Parts Otomotif Berbahan Karet di CV Regina Eka Pratiwi
}

\author{
Business Strategic Plan Made of Rubber Automotive Spare Parts \\ at CV Regina Eka Pratama
}

\author{
Innas Rovino Katuruni ${ }^{1 *}$, Arief Daryanto ${ }^{2 \#}$, dan Agus Maulana ${ }^{3 \#}$ \\ ${ }^{1}$ Magister Manajemen dan Bisnis, Sekolah Pascasarjana Institut Pertanian Bogor \\ Gedung MB IPB-Jl Raya Pajajaran, Bogor 16151 \\ ${ }^{2}$ Program Pascasarjana Manajemen dan Bisnis, Institut Pertanian Bogor \\ Gedung MB IPB-Jl Raya Pajajaran, Bogor 16151
}

\begin{abstract}
ABSTRAK
Di Indonesia industri otomotif merupakan salah satu industri yang berkembang dengan pesat. Menurut data statistik, setiap tahun sampai awal tahun 2015 jumlah kendaraan yang terjual di Indonesia terus meningkat. Meningkatnya permintaan kendaraan bermotor akan dapat memengaruhi jumlah permintaan akan spare parts. Salah satu perusahaan yang bergerak memproduksi spare parts berbahan dasar karet adalah CV Regina Eka Pratiwi. Perkembangan lingkungan otomotif di Indonesia tidak mendukung perkembangan dalam organisasi perusahaan CV Regina. Ditunjukkan dengan kinerja perusahaan yang dapat dikatakan kurang memuaskan. Penelitian bertujuan menganalisis kondisi bisnis CV Regina Eka Pratiwi, memformulasikan strategi bisnis CV Regina Eka Pratiwi, merekomendasikan kebijakan strategi dan action plan dalam strategi bisnis CV Regina Eka Pratiwi. Penelitian ini dilakukan di CV Regina Eka Pratiwi pada bulan April dan Mei 2015. Contoh penelitian ini menggunakan purposive sampling pada jajaran manajerial yang dianggap memahami kondisi perusahaan menggunakan bantuan kuesioner dan pendekatan deskriptif kualitatif. Tahapan dan metode yang digunakan yaitu menganalisis penyebab utama permasalahan perusahaan, melakukan analisis Internal Factor evaluation (IFE) dan External Factor Evaluation (EFE), analisis matriks Internal External (IE) dan Strengths, Weakneses, opportunities, dan Threats (SWOT), merumuskan strategi prioritas perusahaan dengan metode Quantitative Strategic Planning Matrix (QSPM), dan mengevaluasi gap strategi perusahaan. Dari hasil analisis didapatkan masih banyak kelemahan dalam perusahaan. Peluang yang tinggi mengakibatkan perusahaan masih dapat beroperasi dengan kekuatan yang ada. Dalam IFE nilai kelemahan didapatkan lebih besar dibandingkan dengan kekuatan, sedangkan pada EFE nilai peluang lebih tinggi dibandingkan dengan ancaman. Strategi yang didapatkan adalah bersifat bertahan dan menyerang seiring dengan strategi pada matriks IE yang berupa strategi harvest and divest. QSPM digunakan untuk menentukan prioritas strategi yang dapat diterapkan CV Regina.
\end{abstract}

Kata kunci: otomotif, perencanaan, spare parts berbahan karet, strategi bisnis

\begin{abstract}
Automotive industry is one of the rapidly-growing industry in Indonesia. According to statistical data, sold vehicles per annum are growing more. The increasing demand of vehicles can be able to influence the demand of spare parts. One of the operating company that produces made of rubber-spare parts is CV Regina Eka Pratiwi. The growth of automotive environment in Indonesia doesn't support the growth of company organization of CV Regina. It is shown by the company performance that can be said as unsatisfactory. This research aimed at analyzing the business condition of CV Regina Eka Pratiwi, formulating the business strategic of CV Regina Eka Pratiwi, recommending the strategic policy and

\footnotetext{
*) Korespondensi:

Kebun Raya Residence W17 Bogor; email: i.rovino.k@gmail.com
} 
action plan on the strategic business of CV Regina Eka Pratiwi. This research was conducted at CV Regina Eka Pratiwi on April and May 2015. The sample on this research used purposive sampling on the managerial board that is supposed to understand the company condition using support of questionnaire and descriptive-qualitative approach. The step and method used namely to analyze the main cause of company problem, to do Internal Factor evaluation (IFE) and External Factor Evaluation (EFE) analysis, Internal External (IE) matrix and Strengths, Weakneses, opportunities, dan Threats (SWOT) analysis, to formulate priority strategy of the company through Quantitative Strategic Planning Matrix (QSPM) method, and to evaluate the company strategies. By the analysis output, it is obtained that the company still has many weaknesses. The high opportunity causes the company still able to operate with the existing power. The obtained score in IFE is greater than the strength, the opportunity score in EFE is greater than the threat. Obtained strategy is defense and attack characteristic and the strategy on IE matrix that is harvest and divest strategy. QSPM is used to gain priority strategy that will firstly appplied bu CV Regina

Key words: planning, business strategy, made of rubber-spare parts, Automotive

\section{PENDAHULUAN}

Berdasarkan Korps Lalu Lintas Kepolisian Negara Republik Indonesia (2014) jumlah kendaraan yang masih beroperasi di seluruh Indonesia pada 2013 mencapai 104,2 juta unit, 11\% lebih tinggi dari tahun 2012 yang hanya 94,3 juta unit. Dari total populasi tersebut yang masih menjadi penyumbang terbesar adalah sepeda motor dengan jumlah 86,2 juta unit di seluruh Indonesia, naik $11 \%$ dari tahun sebelumnya yaitu 77,7 juta unit. Jumlah terbesar kedua adalah mobil penumpang dengan 10,54 juta unit, naik $11 \%$ dari tahun sebelumnya yaitu 9,5 juta unit. Populasi mobil barang (truk, pikap, dan lainnya) sejumlah 5,6 juta unit, naik $9 \%$ dari 4,7 juta unit. Meningkatnya permintaan kendaraan bermotor akan dapat memengaruhi jumlah dari permintaan akan spare parts.

Menurut Gabungan Industri Alat-alat Mobil dan Motor (GIAMM 2015) yang merupakan wadah bagi perusahaan komponen otomotif pada tahun 2011 penjualan komponen otomotif mencapai 31 juta unit, ekspor meningkat hingga 134 juta unit, dan produksi meningkat menjadi 245 juta unit. Trend perkembangan produksi dan penjualan komponen ini akan terus meningkat seiring dengan peningkatan produksi kendaraan bermotor di Indonesia. Industri penunjang komponen otomotif juga ikut berkembang, salah satunya industri pembuatan suku cadang berbahan karet. Di Indonesia salah satu perusahaan yang bersaing memproduksi suku cadang dari kendaraan bermotor tersebut adalah PT Astra Otoparts. Astra Otoparts yang membutuhkan komponen berbahan dasar karet yang tidak hanya diproduksi sendiri. Salah satu perusahaan yang memproduksi spare parts dengan bahan dasar karet untuk PT Astra Otoparts adalah PT Indokarlo Perkasa. PT Indokarlo Perkasa memproduksi rubber molded parts, rubber extruded parts/hoses, rubber vibration insulation parts (cushion/ mounting). PT Indokarlo dalam berproduksi menyerahkan sebagian proses produksinya pada lima vendor.

Salah satu vendor PT Indokarlo adalah CV Regina Eka Pratiwi. Berdasarkan direktur utama dari CV Regina, CV Regina memegang 30\% dari total produksi PT Indokarlo, 50\% produk diproduksi oleh PT Indokarlo sendiri dan sisanya $(20 \%)$ diproduksi oleh empat vendor lain yang menjadi rahasia dari PT Indokarlo. Bahan baku yang digunakan oleh CV Regina Eka Pratiwi adalah berupa karet sintetis, yaitu karet alam yang telah dicampur dengan bahan-bahan kimia. Yang menjadi customer CV Regina baru hanya PT Indokarlo. Pasokan bahan baku dan mesin perusahaan disediakan oleh customer, yaitu PT Indokarlo. Produk yang dihasilkan CV Regina sepenuhnya menjadi pasokan PT Indokarlo. Kegiatan produksi CV Regina dilakukan dengan sistem manufaktur.

Pada umumnya sektor-sektor perekonomian Indonesia mengalami peningkatan pertumbuhan. Pada tahun 2014 pertumbuhan kumulatif sektor industri manufaktur terhadap Produk Domestik Bruto (PDB) tanpa migas 5,30 \% sampai Triwulan III tahun 2014. Kinerja perekonomian Indonesia pada triwulan III tahun 2014 terhadap PDB tanpa migas berdasarkan harga konstan meningkat 3,04\% dari Rp691.606,7 miliar menjadi Rp712.620,9 miliar. Kontribusi sektor industri manufaktur terhadap PDB pada triwulan III tahun 2014 sebesar Rp. 188.115,6 miliar atau 
23,38\% (BPS 2014). Selama periode triwulan IV tahun 2013 triwulan III tahun 2014, triwulan I tahun 2014 industri manufaktur mengalami penurunan sebesar $0,30 \%$ dibanding triwulan sebelumnya. Sedangkan di triwulan II tahun 2014 meningkat 2,30\% dibandingkan triwulan I tahun 2014 atau meningkat dari indeks produksi 116,91 menjadi 119,21 . Demikian juga di triwulan III tahun 2014 kembali meningkat 1,85\% dibandingkan triwulan sebelumnya (BPS 2014).

Berdasarkan data keuangan CV Regina (2014), pada tahun 2014 perusahaan ini menderita kerugian 1,42 miliar rupiah dan 676 juta rupiah pada tahun 2013. Kinerja yang dapat dikatakan tidak bagus ini tentunya bertentangan dengan kondisi industri manufaktur yang saat ini sedang berkembang di Indonesia. Pemilihan pembuatan rencana strategik bisnis ini disebabkan CV Regina yang belum memiliki strategi bisnis sebelumnya. Selama ini kegiatan bisnisnya hanya sekedar membuat pesanan yang ada, tanpa strategi. Kerugian ini juga menjadi menarik mengingat $\mathrm{CV}$ Regina yang hanya memproduksi barang milik PT Indokarlo. Seharusnya dengan sistem seperti ini kerugian tidak terjadi secara terus menerus. Pembuatan Renstra ini dalam rangka mengembalikan posisi perusahaan kedalam posisi yang dapat menguntungkan, berkembang, dan memiliki daya saing. Perencanaan ini dibuat dengan menggunakan pendekatan manajemen strategik pada skala perusahaan. Mengacu kebutuhan akan strategi bisnis perusahaan tujuan penelitian ini adalah menganalisis kerugian bisnis CV Regina Eka Pratiwi, memformulasikan strategi bisnis CV Regina Eka Pratiwi untuk mengatasi kerugian, dan merekomendasikan strategi bisnis CV Regina Eka Pratiwi.

\section{METODE PENELITIAN}

Penelitian ini dilakukan di CV Regina Eka Pratiwi selama bulan Maret sampai dengan April Tahun 2015. Responden internal dalam penelitian ini adalah Direktur Utama, Manajer Produksi, Manajer PPIC, Kontrol Sub-kontraktor \& HRD. Responden eksternal dalam penelitian ini adalah pihak PT Putra Alpindo Buana yang langsung membawahi CV Regina, perwakilan pihak PT Indokarlo dan pemerintah daerah sekitar. Data yang digunakan dalam penelitian ini merupakan data primer dan data sekunder. Data primer berupa data hasil observasi langsung dalam bentuk wawancara menggunakan bantuan kuesioner. Sebelum pengisian kuesioner, terlebih dahulu dilakukan Focus Group Discussion (FGD) dengan seluruh responden internal. Kuesioner pada penelitian ini terdiri dari empat bagian kuesioner, yaitu bagian harapan stakeholder, bagian Strengths, Weakneses, opportunities, dan Threats (SWOT), bagian Internal Factor Evaluation (IFE), External Factor Evaluation (EFE), dan bagian Quantitative Strategic Planning Matrix (QSPM). Data sekunder CV Regina Eka Pratiwi diperoleh dari data laporan perusahaan dan data lain yang berhubungan dengan penelitian ini, serta berasal dari berbagai sumber.

Data yang diperoleh diolah dan dianalisis secara deskriptif kuantitatif seperti pada penelitian Aji (2014) menurut tahapan berikut:

1. Menganalisis penyebab utama kerugian berdasarkan laporan keuangan.

Analisis ini akan dilihat dari laporan keuangan CV Regina Eka Pratiwi. Analisis ini dimulai dari faktor apa dalam laporan keuangan yang menyebabkan kerugian. Laporan keuangan yang dianalisis adalah laporan laba rugi, laporan beban usaha, dan laporan harga pokok produksi. Dari laporan keuangan ini dilihat sebenarnya dari faktor apa kerugian tersebut berasal. Apakah berasal dari terlalu tingginya biaya, terlalu rendahnya harga, atau dari faktor-faktor lainnya.

\section{Melakukan Evaluasi Faktor Internal dan Eksternal}

Faktor internal dan eksternal diperoleh dari analisis SWOT seperti penelitian oleh Leung (2010). Jumlah faktor tidak memiliki pengaruh terhadap kisaran total skor pembobotan karena total bobot berjumlah 1,00. Penentuan bobot setiap peubah dilakukan dengan mengajukan identifikasi faktor strategik eksternal dan internal kepada pihak manajemen yang menentukan kebijakan perusahaan dengan menggunakan metode Pairwise Comparison (Kinnear dan Taylor, 1991). Metode ini digunakan untuk memberikan penilaian tentang bobot terhadap setiap faktor penentu internal dan eksternal. Setiap peubah digunakan skala 1,2, dan 3 untuk menentukan bobot. Skala yang digunakan adalah:

$1=$ jika indikator horizontal kurang penting dibanding indikator vertikal

$2=$ jika indikator horizontal sama penting dibanding indikator vertikal

$3=$ jika indikator horizontal lebih penting dibanding indikator vertikal

Cara membaca perbandingan dimulai dari peubah pada indikator horizontal dibandingkan 
dengan peubah pada indikator vertikal secara konsisten. Bobot setiap peubah diperoleh dengan menentukan nilai setiap peubah terhadap jumlah nilai keseluruhan peubah dengan menggunakan rumus (Kinnear dan Taylor, 1991).

$$
\alpha i=\frac{X i}{\sum X i}
$$

$$
\begin{aligned}
& \text { Keterangan: } \\
& \begin{array}{ll}
\alpha \mathrm{i} & =\text { bobot faktor } \\
\mathrm{X} \mathrm{i} & =\text { nilai variable } \mathrm{ke}-\mathrm{i} \\
\Sigma \mathrm{X} & =\text { total nilai peubah }
\end{array}
\end{aligned}
$$

Penentuan rating adalah langkah selanjutnya setelah melakukan pembobotan. Penentuan peringkat atau rating antara 1-4 pada setiap faktor internal dan eksternal utama untuk menggambarkan seberapa efektif strategi perusahaan saat ini dalam merespons faktor strategi yang ada. Pemberian rating untuk faktor internal (IFE) dengan skala $1=$ kelemahan utama, $2=$ kelemahan minor, $3=$ kekuatan minor, dan $4=$ kekuatan utama. Berikutnya untuk faktor eksternal (EFE) dengan skala $1=$ respon perusahaan jelek, $2=$ respon perusahaan rataan, $3=$ respon perusahaan di atas rataan, dan $4=$ respon perusahaan luar biasa (David 2009).

Nilai dari pembobotan dikalikan dengan peringkat dari tiap faktor untuk menentukan skor bobot terhadap masing-masing faktor. Penentuan skor bobot total Penjumlahan secara vertikal dari semua hasil kali antara nilai dari pembobotan dengan peringkat. Total skor pembobotan berkisar antara 1,0-4,0 dengan skor rataan 2,5. Jika total skor pembobotan IFE di bawah 2,5 mencirikan organisasi yang lemah secara internal, namun bila berada di atas 2,5 mengindikasikan posisi internal yang kuat. Jika total skor pembobotan EFE 1,0 menunjukkkan bahwa strategi perusahaan tidak mampu memanfaatkan peluang yang ada atau menghindari ancaman yang muncul dan jika skor bobot total 4,0 mengindikasikan bahwa perusahaan merespons peluang dan ancaman yang ada dengan sangat baik (David, 2009).

\section{Analisis Matriks IE dan SWOT}

Matriks IE berguna untuk menempat-kan divisi organisasi dalam sebuah diagram sistematis dengan tampilan sembilan sel. Matriks IE didasarkan pada dua dimensi kunci, yaitu skor bobot total IFE pada sumbu $x$ dan skor bobot total EFE pada sumbu $y$. Pada sumbu $x$ dari matriks IE, skor bobot total IFE 1,0-1,99 menunjukan posisi internal yang lemah, skor 2,0-2,99 sedang, dan 3,04,0 adalah kuat. Pada sumbu y, skor bobot total EFE 1,0-1,99 rendah, skor 2,0-2,99 sedang, dan skor 3,0-4,0 adalah tinggi.

Matriks IE dapat dibagi menjadi tiga bagian dasar yang mempunyai implikasi strategi berbeda-beda. Pertama, ketentuan untuk divisidivisi yang masuk dalam sel I, II, atau IV digambarkan sebagai tumbuh dan berkembang (grow and build). Kedua, sel III, V, atau VII digambarkan sebagai menjaga dan mempertahankan (hold and maintain). Ketiga, sel VI, VIII, atau IX adalah panen atau divestasi (harvest or divest). Matriks IE ditunjukkan pada Gambar 3.

Tahapan setelah mencocokkan dengan matriks IE adalah mencocokkan dengan matriks SWOT seperti pada. Matriks SWOT merupakan alat untuk membantu manajer mengembangkan empat tipe strategi yaitu SO (strengths-opportunities), WO (weakness-opportunities), ST (strengthsthreats), dan WT (weakness-threats). Mencocokkan faktor eks-ternal dan internal kunci merupakan hal paling sulit dalam mengembangkan matriks SWOT dan membutuhkan penilaian yang baik (David, 2009).

Strategi SO menggunakan kekuatan internal perusahaan untuk memanfaatkan peluang eksternal. Strategi WO bertujuan untuk memperbaiki kelemahan internal dengan memanfaatkan peluang eksternal. Strategi ST menggunakan kekuatan perusahaan untuk menghindari atau mengurangi pengaruh dari ancaman eksternal. Strategi WT adalah taktik defensif yang diarahkan pada pengurangan kelemahan internal dan menghindari ancaman eksternal. Matriks SWOT terdiri atas sembilan sel, terdiri dari empat sel faktor kunci, empat sel strategi, dan satu sel kosong (sel di kiri atas). Empat sel strategi (SO, WO, ST, dan WT) dikembangkan setelah menyelesaikan empat sel faktor kunci ( $\mathrm{S}, \mathrm{W}, \mathrm{O}$, dan T).

4. Merumuskan strategi prioritas perusahaan dengan QSPM

Pembuatan peringkat strategi yang menghasilkan daftar berprioritas digunakan teknik analisis QSPM yang didesain untuk menentukan daya tarik relatif dari tindakan yang layak. QSPM atau matriks perencanaan strategi kuantitatif adalah alat yang memungkinkan penyusun strategi untuk mengevaluasi alternatif strategi secara obyektif berdasarkan faktor keberhasilan kunci internal dan eksternal yang telah 
diidentifikasi sebelumnya. Secara konsep, QSPM menentukan daya tarik relatif dari berbagai strategi berdasarkan seberapa jauh faktor keberhasilan kunci internal dan eksternal yang dapat dimanfaatkan dan diperbaiki (David, 2009). Tahapan kerja pengolahan data dengan menggunakan metode QSPM (David, 2009) adalah:

a. Membuat daftar peluang dan ancaman eksternal, serta kekuatan dan kelemahan internal kunci perusahaan pada kolom kiri dalam QSPM. Informasi ini harus diambil secara langsung dari matriks EFE dan IFE.

b. Pemberian bobot untuk masing-masing faktor internal dan eksternal. Bobot ini identik dengan yang ada pada matriks EFE dan IFE. Bobot disajikan dalam kolom di samping kanan faktor keberhasilan kunci internal dan eksternal.

c. Evaluasi matriks tahap pencocokan dan identifikasi alternatif strategi yang harus dipertimbangkan organisasi untuk diimplementasikan. Strategi-strategi ini dicatat pada baris atas dari QSPM. Strategi dikelompokkan ke dalam set independen jika memungkinkan.

d. Menentukan nilai daya tarik (Attractiveness Score atau $A S)$, didefinisikan sebagai angka yang mengindikasikan daya tarik relatif dari masing-masing strategi dalam set alternatif tertentu. Jangkauan untuk nilai daya tarik adalah:

$$
\begin{aligned}
& 1=\text { tidak menarik } \\
& 2=\text { agak menarik } \\
& 3=\text { cukup menarik } \\
& 4=\text { sangat menarik }
\end{aligned}
$$

e. Menghitung total nilai daya tarik (Total Attractiveness Score atau TAS), didefinisikan sebagai hasil dari pengalian bobot (langkah 2) dengan nilai daya tarik (langkah 4) dalam masing-masing baris. Semakin tinggi total nilai daya tarik, maka semakin menarik alternatif strategi tersebut.

Penjumlahan total nilai daya tarik dengan cara menambahkan total nilai daya tarik dalam masing-masing kolom strategi dari QSPM. Penjumlahan total nilai daya tarik (STAS) mengungkapkan strategi mana yang paling menarik dari setiap set alternatif. Nilai yang lebih tinggi mengindikasikan strategi lebih menarik, mempertimbangkan semua faktor internal dan eksternal yang relevan untuk memengaruhi keputusan strategik.
5. Mengevaluasi gap antara strategi lama perusahaan dengan strategi baru yang akan diterapkan.

Evaluasi gap ini dilakukan dengan menggunakan kerangka evaluasi strategi Rumelt. Dalam mengukur kinerja organiasi, aktifitas ini termasuk membandingkan hasil yang diharapkan dengan hasil yang sebenarnya, menyelidiki penyimpangan dari rencana, mengevaluasi prestasi individual dan menyimak kemajuan yang dibuat ke arah pencapaian sasaran yang dinyatakan. Sasaran jangka panjang dan sasaran tahunan biasanya dipakai dalam proses ini. Kriteria untuk mengevaluasi strategi harus dapat diukur dan mudah dibuktikan. Evaluasi strategi didasarkan pada kriteria kuantitatif maupun kualitatif. Menurut Rumelt (1980), ada empat kriteria dalam evaluasi strategi, yaitu:

a. Konsistensi (consistency)

Sebuah strategi tidak boleh memiliki tujuan dan kebijakan yang tidak konsisten. Tiga pedoman yang mendasari konsistensi strategi adalah persoalan manajerial, keberhasilan departemen dan isu kebijakan organisasi.

b. Kesesuaian (consonance)

Kesesuaian mengacu pada kebutuhan para perencana strategi untuk mengkaji serangkaian tren maupun masing-masing tren dalam mengevaluasi strategi. Untuk itu perlu mencermati serangkaian tren, termasuk tren individu. Kebanyakan tren merupakan hasil interaksi antar tren.

c. Keunggulan (advantage)

Sebuah strategi harus mendorong penciptaan dan/atau mempertahankan keunggulan kompetitif di bidang kegiatan tertentu. Keunggulan kompetitif biasanya merupakan hasil dari keunggulan sumber daya, keterampilan dan posisi.

d. Kelayakan (feasibility)

Sebuah strategi tidak boleh terlalu banyak membebani sumber daya yang ada maupun tidak boleh menciptakan sub masalah yang tidak dapat dipecahkan.

\section{HASIL DAN PEMBAHASAN}

CV Regina Eka Pratiwi merupakan sebuah perusahaan manufaktur yang bergerak dalam bidang jasa suku cadang otomotif berbahan dasar karet. Perusahaan ini berlokasi di Sukabumi dengan Alamat Jl. Lingkar Selatan Jayaraksa Baros No 68 Sukabumi, Jawa Barat. Visi CV 
Regina adalah Menjadi perusahaan manufaktur terbaik yang dapat menopang industri besar di Indonesia. CV Regina memiliki Misi, yaitu mendukung industri besar dalam mendorong pertumbuhan ekonomi nasional dan mengembangkan usaha dengan memanfaatkan sumber daya manusia (SDM) secara efektif dan efisien. Produksi CV Regina 30\% dari total produksi PT Indokarlo. Item yang diproduksi saat ini oleh CV Regina adalah 181. Produk yang dihasilkan CV Regina secara umum dikelompokkan kedalam tiga jenis produk, yaitu rubber molded parts, rubber extruded parts/hoses, rubber vibration insulation parts (cushion/mounting).

Produksi CV Regina 30\% dari total produksi PT Indokarlo. Jenis produk yang diproduksi saat ini oleh CV Regina sejumlah 181. Produk yang dihasilkan CV Regina secara umum dikelompokkan kedalam tiga jenis produk, yaitu rubber molded parts, rubber extruded parts/hoses, rubber vibration insulation parts (cushion/mounting). Mesin CV Regina yang digunakan untuk berproduksi secara total ada 44 yang terdapat dalam 69 tabel. Bahan baku yang digunakan oleh CV Regina Eka Pratiwi berupa karet sintetis. Customer CV Regina baru hanya PT Indokarlo. Pasokan bahan baku dan mesin perusahaan juga disediakan oleh PT Indokarlo. Produk yang dihasilkan oleh CV Regina sepenuhnya menjadi pasokan PT Indokarlo. Kegiatan produksi CV Regina dilakukan dengan sistem manufaktur. Sistem operasional CV Regina mengadopsi sistem yang dijalankan pada PT Indokarlo. Strategi yang sebelumnya diterapkan oleh CV Regina adalah strategi memproduksi barang sesuai dengan pesanan. Dalam strategi ini kegiatan CV Regina hanya memproduksi barang sesuai dengan pesanan yang masuk. Strategi ini tidak mencakup kegiatan-kegiatan lain selain kegiatan produksi barang.

Berdasarkan SENADA (2007) PT Indokarlo melalui CV Regina memproduksi suku cadang otomotif yang masuk ke dalam third tier manufacturers, karena CV Regina memproduksi molding parts. Third tier manufacturers atau manufaktur tingkat ketiga memiliki peluang pasar besar, walaupun tidak memproduksi suku cadang secara keseluruhan. Peluang pasar yang besar ini karena memiliki pangsa pasar yang tinggi. Hal ini mengakibatkan CV Regina memiliki 30\% produksi pada PT Indokarlo akan memiliki pesanan produk berkelanjutan dan dengan intensitas tinggi, mengingat PT Indokarlo berada pada tingkat ketiga.

Dunia otomotif di Indonesia sendiri kian menjadi peluang dan ancaman bagi CV Regina. Selama beberapa tahun terakhir, pasar komponen otomotif di Indonesia telah meningkat nyata, sebagian besar untuk kelas menengah. Kurangnya sistem angkutan umum sedikit banyak telah memaksa orang untuk berinvestasi dalam bentuk kepemilikan alat transportasi atau kendaraan bermotor. Ada beberapa kelemahan untuk membeli model mobil baru di Indonesia yang memaksa orang untuk mencari suku cadang otomotif untuk memperbaiki kendaraan model yang lebih tua dibandingkan membeli model kendaraan baru (Ipsos, 2013).

Berdasarkan data dari KPMG (2014), CV Regina memiliki peluang besar untuk terus berproduksi. Di Indonesia, meningkatnya kalangan menengah dengan kepercayaan diri tinggi telah menjadikan konsumsi kendaraan bermotor tetap tinggi. Tingginya konsumsi ini didukung juga dengan rendahnya suku bunga bank BI dan prediksi peningkatan GDP 5,4\%-6,4\% antara tahun 2014 dan 2017. Faktor tersebut yang mengakibatkan pertumbuhan positif mobil yang diperkirakan akan terus sampai tahun 2016 dengan sales $11,1 \%$ dari tahun 2005 sampai tahun 2012 dan peningkatan produksi 11,4\% dari tahun 2005-2012. Pada tahun 2013 penjualan mobil mencapai 1,2 juta unit dimana $70 \%$ mobil yang yang terjual merupakan mobil untuk penumpang dan sisanya merupakan mobil barang seperti truck, bus, dan pickup. Bersamaan dengan itu, penetrasi pasar roda dua 25\%, lebih tinggi 3,5\% jika dibandingkan dengan roda empat. Diharapkan LCGC akan mengubah pilihan konsumen dari roda dua menjadi roda empat. CV Regina juga semakin diuntungkan, karena memproduksi barang untuk PT Indokarlo yang notabene adalah member of Astra, dimana Astra sendiri memegang 54\% pasar di Indonesia (KPMG, 2014).

Berdasarkan KPMG (2014), CV Regina akan menghadapi tantangan untuk terus dapar menjalankan kegiatan bisnisnya di Indonesia. Infrastruktur yang kurang memadai menjadikan proses distribusi yang terganggu dan kurang lancar. Pengetatan regulasi pemerintah terkait peminjaman uang dari bank yang membutuhkan 30\% Down Payment. Melemahnya rupiah menjadi hal paling dirasakan secara menyeluruh. Melemahnya rupiah menjadikan naiknya harga barang yang menjadikan mata uang asing sebagai 
acuan. Harga minyak dunia juga memengaruhi harga BBM di Indonesia. Harga BBM yang tinggi akan memengaruhi biaya pengiriman bahan baku dan barang hasil produksi ke konsumen. Generasi muda akan terus berinvestasi dalam kendaraan, sehingga kebutuhan untuk suku cadang otomotif di wilayah ini akan terus meningkat selama beberapa tahun. Kendaraan bertambah tua, maka perawatan rutin dan perbaikan wajib menjadi perlu supaya kendaraan tetap dalam kondisi yang layak (Ipsos, 2013). Industri otomotif di Indonesia terus berkembang, sehingga akan ada dampak langsung pada industri pendukung lainnya di dalam negeri, termasuk industri komponen otomotif yang menyediakan pembuat kendaraan bermotor komponen yang diperlukan untuk merakit kendaraan. Menurut Ipsos (2013) pada akhir tahun 2012 diperkirakan bahwa pasar industri komponen otomotif mencapai 78 triliun rupiah.

\section{Analisis Laporan Keuangan}

Berdasarkan hasil wawancara dengan pihak direktur perusahaan diperoleh keterangan bahwa saat ini kondisi keuangan perusahaan sedang dalam masa perkembangan setelah mengalami kerugian berturut-turut. Berdasarkan laporan laba rugi perusahaan, faktor terbesar yang menyebabkan kerugian ini adalah tingginya biaya produksi dan harga penjualan yang kurang mencukupi, sehingga menjadikan biaya produksi lebih tinggi dibandingkan dengan harga penjualan. Beban usaha sebagian besar dikarenakan beban administrasi dan beban umum. Biaya produksi yang tinggi disebabkan oleh tingginya upah karyawan dan biaya listrik pada beban produksi tak langsung.

\section{Evaluasi Faktor Internal dan Eksternal}

Identifikasi terhadap faktor internal perusahaan menghasilkan sejumlah faktor strategik yang berupa kekuatan dan kelemahan perusahaan. Setelah itu kepada setiap faktor tersebut diberikan pembobotan dan pemberian rating oleh masing-masing responden. Hasilnya diformulasikan dalam bentuk matriks IFE . Skor yang diperoleh dari matriks IFE menunjukkan kemampuan perusahaan dalam memanfaatkan kekuatan yang dimiliki dan mengatasi kelemahan yang ada (David, 2009 dan Hunger, 2012). Hasil analisis IFE dapat dilihat pada Tabel 1.

Matriks IFE menunjukkan hasil penelitian responden terhadap faktor internal perusahaan.
Matriks Evaluasi Faktor Internal (IFE) menghasilkan total nilai tertimbang 1,90. Total nilai tertimbang tersebut menunjukkan posisi internal perusahaan berada di bawah rataan $(<2,50)$. Hal ini menggambarkan bahwa CV Regina belum memiliki kemampuan rataan atau belum memanfaatkan kekuatan dan meminimalkan kelemahan yang terdapat pada internal perusahaan. Kekuatan utama dari hasil perhitungan matriks IFE, yang menjadi kekuatan utama CV Regina adalah tersedianya transportasi untuk pengiriman dengan skor 0,33. Faktor lain yang menjadi kekuatan CV Regina adalah tersedianya teknologi produksi dengan nilai terbobot 0,30 .

Kelemahan utama dari CV Regina adalah keuangan yang sedang merugi dengan rating berbobot 0,09 . Selain itu, kelemahan yang cukup menonjol dari CV Regina adalah penanganan kerusakakan mesin yang lambat dengan rating berbobot 0,11. Dari hasil pengidentifikasian faktor-faktor eksternal yang memengaruhi strategi bisnis perusahaan, maka selanjutnya dievaluasi respon perusahaan terhadap masingmasing faktor sehingga diketahui seberapa besar respon perusahaan terhadap faktor-faktor strategis eksternal peluang dan ancaman tersebut. Hasil analisis EFE dapat dilihat pada Hasil perhitungan matriks EFE, yaitu total nilai tertimbang 2,10. Total nilai tertimbang tersebut menunjukkan bahwa posisi eksternal perusahaan berada di bawah rataan $(<2,50)$. Hal ini menggambarkan bahwa CV Regina belum memiliki kemampuan rataan atau belum dapat memanfaatkan peluang dan mengantisipasi ancaman yang terdapat pada eksternal perusahaan.

Faktor peluang yang direspon paling tinggi dalam persaingan yang dihadapi perusahaan adalah besarnya angka pengguna kendaraan bermotor dengan nilai tertimbang tertinggi 0,30 . Faktor tingginya permintaan kendaraan bermotor ini sesuai dengan data dari KPMG (2014) dan Ipsos (2013). Selain faktor permintaan kendaraan bermotor yang tinggi, faktor eksternal lain yang direspon dan menjadi peluang bagi perusahaan CV Regina adalah customer CV Regina merupakan perusahaan besar dengan nilai berbobot 0,28. Yang menjadi customer CV Regina saat ini adalah PT Indokarlo yang merupakan salah satu member of Astra. Berdasarkan data dari KPMG (2014) dan Ipsos (2013) dan SENADA (2007), Astra merupakan salah satu pemain utama dalam dunia otomotif di Indonesia. Faktor ancaman yang paling besar mendapat respon dari perusahaan 
adalah faktor melemahnya rupiah dengan nilai tertimbang 0,07. Ancaman lain yang direspon oleh perusahaan adalah kenaikan UMR dan listrik dengan nilai skor terbobot 0,09 .

\section{Formulasi Strategi Perusahaan}

Formulasi strategi ini diawali dengan melakukan analisis matriks IE pada CV Regina seperti pada penelitian Ismarsudi (2011), Mostafavi (2015), dan Nainggolan (2010). Tujuan dari penggunaan Matriks IE adalah memperoleh grand strategy, sehingga perusahaan dapat menentukan apakah harus dikembangkan, dipertahankan, atau dilepas. Dengan disusunnya matriks IE maka diketahui posisi perusahaan saat ini, sehingga memudahkan proses penentuan dan pemilihan alternatif strategi yang akan diterapkan. Hasil analisis matriks IE diperoleh dengan cara menggabungkan analisis matriks IFE yang dipetakan pada sumbu $\mathrm{x}$ dan matriks EFE yang dipetakan pada sumbu y. Dari hasil pemetaan matriks IE CV Regina menempati sel VI (Gambar 1) dengan skor terbobot dari evaluasi faktor internal dan evaluasi faktor eksternal $(1,84 ; 2,64)$. Kondisi ini menunjukkan bahwa perusahaan berada pada kondisi harvest and divest (panen atau divestasi).

Tabel 1. IFE CV Regina

\begin{tabular}{llll}
\hline Kekuatan & Bobot (a) & Rating (b) & Rating Berbobot (axb) \\
\hline Tersedia tools untuk produksi & 0,1 & 3 & 0,30 \\
Tersedia teknologi untuk staff & 0,09 & 3 & 0,27 \\
Tersedia transportasi untuk pengiriman & 0,11 & 3 & 0,33 \\
Pembaruan lembar periksa & 0,07 & 3 & 0,21 \\
\hline & & & $\mathbf{1 , 1 1}$ \\
\hline Kelemahan & Bobot & Rating & Rating Berbobot \\
\hline Mesin menganggur 50\% & 0,13 & 1 & 0,13 \\
Kondisi keuangan merugi & 0,09 & 1 & 0,09 \\
Belum memiliki sertifikasi mutu ISO & 0,07 & 2 & 0,14 \\
Penanganan kerusakan mesin lambat & 0,11 & 1 & 0,11 \\
Pelatihan terhadap karyawan masih kurang & 0,09 & 2 & 0,18 \\
Average linestop 50\% & 0,14 & 1 & 0,14 \\
\hline & & & $\mathbf{0 , 7 9}$ \\
\hline Total IFE & & & $\mathbf{1 , 9 0}$ \\
\hline
\end{tabular}

Tabel 2. EFE CV Regina

\begin{tabular}{llll}
\hline Peluang & Bobot (a) & Rating (b) & Rating Berbobot (axb) \\
\hline Tingginya permintaan kendaraan bermotor & 0,13 & 2 & 0,26 \\
Gejolak serikat pekerja masih rendah & 0,08 & 1 & 0,08 \\
Customer merupakan perusahaan besar & 0,07 & 4 & 0,28 \\
Meningkatnya industri manufaktur & 0,08 & 1 & 0,08 \\
Tren permintaan kendaraan bermotor yang stabil & 0,1 & 2 & 0,20 \\
Besarnya angka pengguna kendaraan bermotor & 0,1 & 3 & 0,30 \\
\hline & & & $\mathbf{1 , 2 0}$ \\
\hline Ancaman & Bobot & Rating & Rating Berbobot \\
\hline Pemenuhan pemesanan bahan baku tidak maksimal & 0,1 & 2 & 0,20 \\
Infrastruktur umum kurang memadai & 0,09 & 3 & 0,27 \\
Kenaikan UMR dan listrik & 0,09 & 1 & 0,09 \\
Harga BBM naik & 0,09 & 3 & 0,27 \\
Melemahnya rupiah & 0,07 & 1 & 0,07 \\
\hline & & & $\mathbf{0 , 9 0}$ \\
\hline Total EFE & & $\mathbf{2 , 1 0}$ \\
\hline
\end{tabular}


Total Skor Terbobot IFE

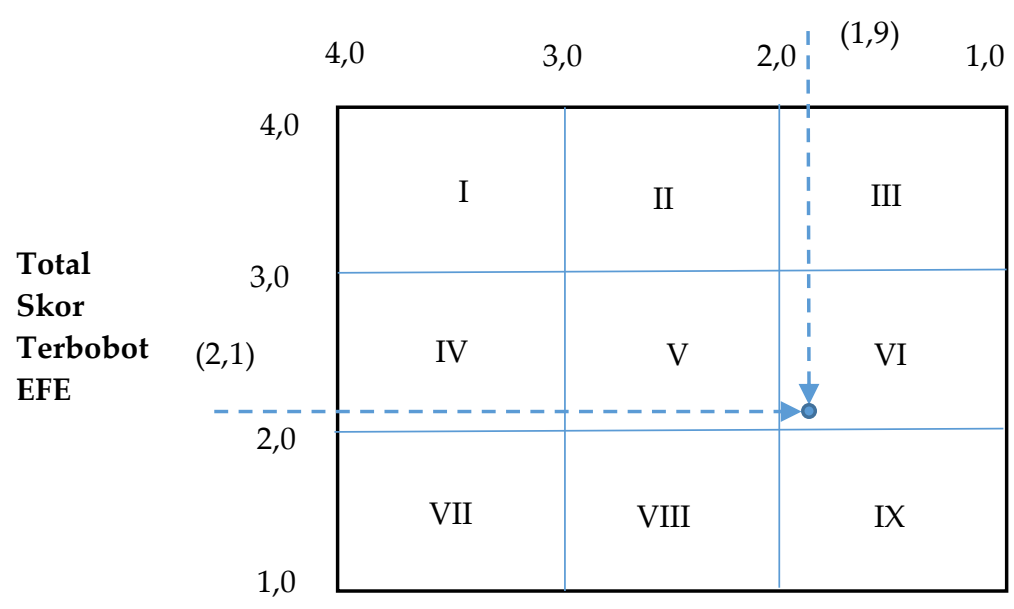

Gambar 1. Matriks IE CV Regina Eka Pratiwi

Alternatif strategi yang dapat digunakan CV Regina pada kuadran VI adalah daerah panen atau divestasi (harvest and divest). Pada posisi harvest and divest yang dapat dilakukan adalah berusaha memper-oleh laba dan arus kas jangka pendek atau menghentikan bisnis tersebut. Posisi harvest and divest ini sesuai dengan kondisi $\mathrm{CV}$ Regina yang terus mengalami kerugian. Strategi yang dibutuhkan menurut matriks IE sesuai dengan yang seharusnya dilakukan oleh $\mathrm{CV}$ Regina sekarang ini, yaitu memperoleh laba jangka pendek. Pemilihan menutup usaha tidak dipertimbangkan karena mengingat masih adanya peluang yang dapat dicapai CV Regina untuk memperbaiki kerugian ini. Matriks IE hanya menghasilkan gambaran strategi secara umum yang dapat dilakukan tanpa mengaitkan dengan kekuatan dan kelemahan perusahaan serta peluang dan ancaman yang dihadapi perusahaan.

Setelah diperoleh Grand Strategy menggunakan matriks IE maka selanjutnya digunakan matriks SWOT seperti pada penelitian oleh Nainggolan (2010), Hero (2008), dan Juhana (2011). Analisis matriks SWOT merupakan alat analisis yang menggambarkan bagaimana manajemen perusahaan dapat merumuskan alternatif strategi yang dapat dijalankan perusahaan berdasarkan pada penyesuaian antara peluang dan ancaman dengan kekuatan, serta kelemahan yang dimiliki perusahaan (David, 2009 dan Hunger, 2012). Hasil strategi yang dirumuskan pada matriks SWOT ini merupakan tindak lanjut dari grand strategy yang didapat dari matriks IE (Kunandi, 2013). Alternatif strategi yang dapat diperoleh adalah:

\section{A. $\mathrm{SO}$}

Strategi SO adalah strategi yang menggunakan kekuatan internal perusahaan untuk memanfaatkan peluang eksternal. Berikut strategi SO yang dapat dilakukan oleh perusahaan CV Regina adalah Ekspansi Bisnis pada customer baru (S1, S2, S3, S4, S5, S6, O1, O2, O3, O4, O5, O6, O7, O8). Strategi Ekspansi Bisnis pada customer baru merupakan strategi yang dikembangkan dari strategi penetrasi pasar dan pengembangan produk pada matriks IE dan didukung oleh kekuatan-kekuatan yang dimiliki perusahaan guna memanfaatkan seluruh peluang yang ada.

\section{B. WO}

Strategi WO adalah strategi yang bertujuan memperbaiki kelemahan internal perusahaan dengan memanfaatkan peluang eksternal. Strategi WO bagi perusahaan CV Regina dapat dirumuskan sebagai berikut Meningkatkan mutu sistem produksi (W4, W5, W6, W7, W8, O1, O2, O3, O4, O5, O6, O7, O8) dan Penguatan posisi perusahaan pada customer (W1, W2, W3, O1, O2, O3, O4, O5, O6, O7, O8). Strategi WO ini merupakan pengembangan dari strategi penetrasi pasar pada matriks IE yang bertujuan untuk peningkatan penjualan dan pangsa pasar.

\section{ST}

Strategi ST adalah strategi yang menggunakan kekuatan internal perusahaan untuk menghindari atau mengurangi pengaruh ancaman eksternal. Strategi ST bagi perusahaan CV Regina dapat dirumuskan yang terdiri dari Penerapan manajemen mutu secara terpadu (S1, S2, S3, S4, S5, S6, T1, T2, T3, T4, T5). 
D. WT

Strategi WT adalah strategi yang ber-tujuan untuk mengurangi kelemahan internal perusahaan dan menghindari ancaman eks-ternal. Strategi WT bagi perusahaan CV REGINA dapat dirumuskan melalui pembenahan efektifitas dan efisiensi produksi (W1, W2, W3 W4, W5, W6, W7, W8, T1, $\mathrm{T} 2, \mathrm{~T} 3, \mathrm{~T} 4, \mathrm{~T} 5)$.

\section{Analisis QSPM}

QSPM merupakan alat yang memungkinkan penyusun strategi mengevaluasi alternatif strategi yang telah dirumuskan secara obyektif berdasarkan faktor-faktor internal dan eksternal yang telah diidentifikasi sebelumnya (David, 2009). Strategi-strategi yang tercipta berdasarkan posisi perusahaan pada matriks IE dan dirumuskan secara lebih mendalam pada matriks SWOT dievaluasi apakah strategi-strategi tersebut menarik untuk menghadapi peluang dan ancaman yang dihadapi perusahaan dengan kekuatan dan kelemahan yang dimiliki perusahaan seperti pada Indariawati (2011) dan Mostafavi (2015). Hasil akhir dari analisis QSPM berupa TAS atau total skor daya tarik yang merupakan penjumlahan hasil perkalian rataan AS atau nilai daya tarik suatu strategi terhadap faktor internal atau eksternal tertentu dengan rataan bobot faktor internal dan eksternal yang telah dirumuskan dalam matriks IFE dan EFE. Nilai TAS yang dihasilkan lalu diurutkan berdasarkan besar nilainya. Urutan nilai TAS menggambarkan urutan prioritas strategi untuk dilaksanakan oleh perusahaan. Strategi dengan nilai TAS tertinggi adalah strategi yang paling diprioritaskan oleh perusahaan untuk mengembangkan pemasarannya. Urutan prioritas strategi berdasarkan matriks QSPM CV Regina diperlihatkan dalam Tabel 3.

Tabel 3. QSPM CV Regina

\begin{tabular}{lcc}
\hline Strategi & TAS & Prioritas \\
\hline S1 (SO) & 7,08 & 4 \\
S2 (ST) & 7,11 & 3 \\
S3 (WO) & 7,20 & 1 \\
S4 (WT) & 7,17 & 2 \\
\hline
\end{tabular}

Analisis QSPM pada alternatif strategi yang dirumuskan dalam matriks SWOT CV Regina menghasilkan nilai TAS tertinggi untuk strategi 3, yaitu strategi WO dengan nilai TAS 7,20. Dalam strategi WO ini strategi yang dapat diterapkan adalah Meningkatkan mutu sistem produksi, dan penguatan posisi perusahaan pada customer. Urutan prioritas strategi selanjutnya, yaitu strategi WT $(7,17)$ pembenahan efektifitas dan efisiensi produksi, ST $(7,11)$ penerapan manajemen mutu secara terpadu, dan SO $(7,08)$ Expansi bisnis pada customer baru.

\section{Evaluasi Gap Strategi Perusahaan}

Berdasarkan hasil wawancara dengan responden, strategi lama CV Regina berupa strategi produksi pesanan disusun berdasarkan kondisi lingkungan yang ada pada saat waktu penyusunan. Penyusunan strategi ini telah sesuai dengan kondisi lingkungan pada saat itu. Hasil analisis laporan keuangan menunjukkan bahwa kesalahan yang ada pada strategi sebelumnya terletak pada kesalahan implementasi strategi perusahaan. Kesalahan implementasi ini ditunjukkan oleh kerugian yang diderita CV Regina. Kerugian ini disebabkan oleh terlalu besarnya biaya produksi perusahaan dan kurang tingginya harga jual produk. Kedua hal tersebut menunjukkan pengimplementasian strategi $\mathrm{CV}$ Regina yang kurang baik. Untuk itu perlu dilakulkan evaluasi gap antara strategi CV Regina yang lama dengan strategi yang akan diterapkan CV Regina. Evaluasi gap ini dilakukan dalam rangka mengetahui posisi strategi CV Regina dulu dan kini.

Evaluasi gap strategi CV Regina yang lama dan yang baru disusun menggunakan kerangka evaluasi strategi Rumelt. Menurut Rumelt (1980) ada empat poin dalam kerangka evaluasi strategi. Masing-masing kerangka ini dibahas berdasarkan strategi lama CV Regina yang telah diterapkan sebelumnya. Melalui kerangka Rumelt ini analisis evaluasi strategi CV Regina adalah:

1. Konsistensi (consistency)

Sebuah strategi tidak boleh memiliki tujuan dan kebijakan yang tidak konsisten. Tiga pedoman yang mendasari konsistensi strategi adalah persoalan manajerial, keberhasilan departemen dan isu kebijakan organisasi. Tiga pedoman yang mendasari konsistensi strategi, yaitu persoalan manajerial, keberhasilan departemen dan isu kebijakan organisasi.

Dalam penerapannya, strategi lama CV Regina menunjukkan hasil yang kurang baik. Secara konsistensi strategi ini memberikan konsistensi hasil yang buruk bagi CV Regina. Hasil yang buruk ditunjukkan oleh performa manajerial yang buruk, keberhasil-an departemen 
yang tidak tercapai, dan juga kebijakan organisasi yang tidak tepat. Kesemua hal ini ditunjukkan melalui kerugian yang terus dirasakan CV Regina selama menerapkan strategi lamanya tersebut. Dalam hal ini strategi yang baru disusun diharapkan dapat mengatasi masalah manajerial, departemen, dan juga kebijakan organisasi. Kemampuan mengatasi masalah ini dikarenakan strategi yang baru ini disusun berdasarkan kondisi lingkungan terbaru yang sedang dijalani CV Regina.

\section{Kesesuaian (consonance)}

Kesesuaian mengacu pada kebutuhan para perencana strategi untuk mengkaji serangkaian tren maupun masing-masing tren dalam mengevaluasi strategi. Perlunya mencermati serangkaian tren, termasuk tren individu. Kebanyakan tren merupakan hasil interaksi antar tren. Secara umum strategi lama CV Regina sesuai hanya dengan kegiatan produksinya, namun tidak dengan keseluruhan kegiatan perusahaan. apabila mengikuti trend ada, banyak sekali yang perlu disesuaikan dengan strategi CV Regina yang lama ini. Strategi CV Regina sebelumnya ini tidak dapat mengikuti tren yang ada, karena hanya berdasarkan pada satu hal, yaitu pesanan barang.

Strategi baru CV Regina disusun berdasarkan tren yang ada pada saat ini. Penyusunan strategi ini juga memungkinkan bagi CV Regina untuk secara berkesinambungan terus melakukan pengembangan dan penyesuaian strategi yang ada dengan perkembangan tren di masyarakat yang terus berkembang. Strategi baru CV Regina ini untuk saat ini telah sesuai dengan kondisi lingkungan dan kebutuhan CV Regina akan strategi yang mudah untuk diterapkan dan dikembangkan.

\section{Keunggulan (advantage)}

Sebuah strategi harus mendorong penciptaan dan/atau mempertahankan keunggulan kompetitif di bidang kegiatan tertentu. Keunggulan kompetitif biasanya merupakan hasil dari keunggulan sumber daya, keterampilan dan posisi. Keunggulan kompetitif biasanya merupakan hasil dari keunggulan sumber daya, keterampilan dan posisi.

Pada awalnya strategi lama CV Regina dapat dikatakan memiliki keunggulan. Namun kemudian seiring berjalannya waktu strategi ini jelas tidak memiliki keunggulan lagi ditunjukkan oleh kerugian yang terus menerus diderita perusahaan. Strategi baru CV Regina diharapkan dapat memberikan CV Regina keunggulankeunggulan yang dapat meminimalisisr efek dari kerugian yang telah dideritanya. Keunggulankeunggulan kompetitif yang dimiliki CV Regina berasal dari perkembangan kondisi lingkungan yang dapat secara terus menerus diikuti dan diterapkan dalam penyusunan strategi $\mathrm{CV}$ Regina.

\section{Kelayakan (feasibility)}

Sebuah strategi tidak boleh terlalu banyak membebani sumber daya yang ada maupun tidak boleh menciptakan sub masalah yang tidak dapat dipecahkan. Dari segi kelayakan, jelas strategi ini tidak melibatkan banyak pihak dalam organisasi, namun strategi ini menghasilkan sub masalah yang berkelanjutan dan sulit untuk dipecahkan, yaitu masalah kerugian yang terus menerus diderita. Sub masalah yang diderita ini terjadi, walaupun tidak banyak sumber daya yang terlibat, tetapi eksekusi oleh sumber daya yang terlibat menjadi tidak tepat, sehingga mengakibatkan buruknya implementasi strategi oleh pihak lain.

Strategi baru CV Regina tidak melibat-kan banyak sumber daya, tetapi hanya direktur beserta jajarannya. Penerapan strategi baru ini diyakini tidak menyebabkan sub masalah baru dan juga dapat menyelesaikan sub masalah yang lama, yaitu kerugian. Keyakinan ini timbul dari struktur dan proporsi penyusunan, serta implementasi strategi yang diyakini untuk meminimalisir kesalahan dari sumber daya yang tidak terlibat dalam penyusunan dan implementasi strategi ini.

\section{KESIMPULAN}

Dari hasil penelitian didapatkan kesimpulan bahwa yang menyebabkan kerugian pada $\mathrm{CV}$ Regina adalah kurang efektif dan efisiennya kegiatan produksi perusahaan, sehingga mengakibatkan membengkaknya biaya produksi. Biaya produksi yang tinggi ini tidak diikuti oleh harga jual dari konsumen yang mencukupi. Hasil analisis matriks IE menunjukkan bahwa CV Regina menempati sel VI. Perusahaan berada pada kondisi harvest and divest dengan strategi keuntungan jangka pendek. Strategi yang dirumuskan melalui analisis SWOT, yaitu strategi SO berupa ekspansi bisnis pada customer baru, WO berupa meningkatkan mutu sistem produksi dan penguatan posisi perusahaan pada customer, 
ST berupa penerapan manajemen mutu secara terpadu, dan WT berupa pembenahan efektifitas dan efisiensi produksi. Berdasarkan analisis QSPM didapatkan bahwa yang menjadi strategi prioritas CV Regina adalah strategi WO.

\section{DAFTAR PUSTAKA}

Aji AA. 2014. Strategi pengembangan agribisnis komoditas padi dalam meningkatkan ketahanan pangan Kabupaten Jember. Manajemen dan Agribisnis, 11(1): 60-67.

[BPS] Badan Pusat Statistik. 2014. Perkembangan Indeks Produksi Industri Manufaktur 2012-2014. Badan Pusat Statistik. CV Petratama Persada, Jakarta (ID). ISSN 9789602.

Regina CV. 2014. Laporan Keuangan Perusahaan. Direksi CV Regina

David FR. 2009. Manajemen Strategi Konsep (Terjemahan). Salemba Empat, Jakarta.

[GIAMM] Gabungan Industri Alat-Alat Mobil dan Motor. 2015. Statistics.

http://www.giamm.org/index.php?option =com_fabrik\&view=statistic\&listid=5\&Ite mid=661\# [diacu pada 3 April 2015].

Hero Y, Sudaryanto, Setyowati DJ. 2008. Strategi pemasaran mebel kayu sentra industri kecil Pondok Bambu, Jakarta Timur. JMHT, 14(2): 73-80.

Hunger JD, Wheelen TL. 2012. Strategic management and business policy toward global sustainability. New Jersey (US): Pearson Education Inc.

Indariawati P, Raharja S, Soekarto ST. 2011. Kajian Strategi Pengembangan Usaha Industri Keripik Singkong Perusahaan PT Indti Sari Rasa di Bekasi. Manajemen IKM, 6(2): 99-104.

Ipsos. 2013. Automotive parts industry in Indonesia. Ipsos Business Consulting, Jakarta (ID).

Ismarsudi, Suryani A, Kadarisman D. 2011. Kajian Optimasi Produksi dan Strategi Pengembangan Usaha Produk Fish Jelly (Studi Kasus pada PT "XP" di Jakarta). Manajemen IKM, 6(2): 93-98.
Juhana A, Hubeis M, Pandjaitan NH. 2011. Prospek Ekonomi dan Strategi Pengembangan Kapas Rami Sebagai Bahan Baku Alternatif Industri Tekstil Skala Usaha Kecil (Kasus Koppontren Darussalam, Garut-Jawa Barat). Manajemen IKM, 6(2): 111-116

Kinnear TL, Taylor. 1991. Marketing Research an Applied Approach. Fourth Edition. McGraw Hill. New York (US)

Korps Lalu Lintas Kepolisian Negara Republik Indonesia. 2014. Populasi kendaraan bermotor di Indonesia tembus 104,2 juta unit. http://otomotif.kompas.com/read/2014/04/15/1541211/Populasi.Kendaraan.Ber motor.di.Indonesia.Tembus.104.2.Juta.Uni t [diacu pada 3 April 2015].

KPMG. 2014. Indonesia's Automotive Industry: Navigating 2014. (C) 2014 KPMG International Cooperative.

Kunandi, Arkeman Y, Maulana A. 2013. Strategi peningkatan produksi agroindustri pembenihan lele di Bogor. Manajemen dan Agribisnis, 10(1): 1-10.

Leung BYP. 2010. SWOT dimensional analysis for strategic planning-the case of overseas real estate developers in Guangzhou, China. International Journal of Strategic Property Management 15: 105-122.

Mostafavi SS, Jozi SA. 2015. An enviromental management plan for Iran's accession to the World Trade Organization. Pol. J. Environ. Stud. 24(2): 893-898.

Nainggolan SP, Sumantadinata K, Suryani A. 2010. Strategi Pengembangan Usaha "Nila Puff" dalam Meningkatkan Pendapatan IKM Pengolahan Hasil Perikanan pada $\mathrm{CV}$ " $\mathrm{X}$ " di Cibinong Bogor. Manajemen IKM 5,(2): 132-144.

Rumelt R. 1980. The Evaluation of Business Strategy, New York (US): McGraw-Hill.

[SENADA]. 2007. Automotive component value chain overview, market justificationand strategies for domestic market upgrading. Senada Technical coordinators. 